\title{
PEMBUATAN ALAT PERAGA METAMORFOSIS KUPU-KUPU
}

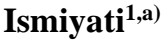 \\ ${ }^{1)}$ UPT Satuan Pendidikan TK Negeri Rembang 1, Jl. Akasia No. 13, Sananwetan, Kota Blitar, Indonesia \\ ${ }^{a)}$ Email: ismiati6661@gmail.com
}

\begin{abstract}
Abstrak
Penelitian ini bertujuan untuk mengetahui tingkat efektivitas alat peraga metamorfosis kupu-kupu. Penggunaan alat peraga dinilai mampu membantu anak dalam menerima ilmu dengan cepat dan tepat. Alat peraga metamorfosis kupu-kupu ini adalah alat yang digunakan untuk belajar memahami konsep siklus hidup kupu-kupu, berbahasa dan ilmu sains sederhana. Alat peraga metamorfosis kupu-kupu dibuat dari kertas asturo, kertas lipat berwarna sebagai komponen utamanya. Gambar proses metamorfosis kupu-kupu dibuat dengan menarik agar mudah dijangkau. Alat peraga ini juga melatih cara anak menyelesaikan masalah dengan menggunakan metode mencoba dan menceritakan. Selain itu, permainan ini motivasi dan membangkitkan anak untuk melakukan eksperimen dan eksperimen dalam proses pertumbuhan dan perkembangannya. Dari hasil penelitian yang dilakukan diketahui bahwa alat peraga metamorfosis kupu-kupu mampu meningkatkan daya ingat anak dan mengembangkan kemampuan anak dalam berbahasa dan berbahasa. Alat peraga metamorfosis kupu-kupu mampu meningkatkan beberapa aspek pada anak seperti nilai agama dan moral, sosial emosional dan kemandirian, fisik motorik, kognitif, bahasa dan seni.
\end{abstract}

Kata kunci: Alat Peraga, Metamorfosis Kupu-kupu, Sains

\begin{abstract}
This study aims to determine the effectiveness of the butterfly metamorphosis props. The use of teaching aids is considered capable of helping children to receive knowledge quickly and precisely. This butterfly metamorphosis teaching aid is a tool used to learn to understand the concept of the butterfly life cycle, language and simple science. The butterfly metamorphosis props are made of asturo paper, colored folding paper as the main component. The picture of the butterfly metamorphosis process is made attractively so that it is easy to reach. This teaching aid also trains children to solve problems using the try and tell method. In addition, this game motivates and awakens children to experiment and experiment in the process of growth and development. From the results of the research conducted, it is known that the butterfly metamorphosis props are able to improve children's memory and develop children's language and language skills. The butterfly metamorphosis props are able to improve several aspects in children such as religious and moral values, social emotional and independence, physical motor, cognitive, language and art.
\end{abstract}

Keywords: Props, Butterfly Metamorphosis, Science

\section{PENDAHULUAN}

Dunia pendidikan tingkat kanakkanak adalah sebuah dunia yang tidak terlepas dari bermain dan juga berbagai alat permainan anak-anak. Salah satu lembaga pendidikan yang berperan penting dalam proses pembelajaran dan peningkatan mutu dunia pendidikan kanak-kanak adalah Taman Kanak-Kanak yang disingkat menjadi TK. Sebagai sebuah taman, tentu saja TK merupakan sebuah tempat belajar dan juga bermain kanak-kanak yang memiliki berbagai sarana dan prasarana untuk mendukung terlaksananya proses pembelajaran dengan baik dan berkualitas.

Pendidikan anak usia dini adalah pendidikan yang ditunjukan bagi anakanak berusia pra sekolah dengan tujuan agar anak dapat mengembangkan potensinya sejak dini, sehingga mereka dapat berkembang secara wajar sebagai 
anak sesuai dengan tingkat usia dan tugas perkembangannya (Asri, 2020). Salah satu sarana yang juga menjadi sumber belajar bagi anak di TK adalah alat pendidikan edukatif yang lebih dikenal dengan APE yang membantu anak untuk memahami bahasa dan sains serta dapat meningkatkan kemampuan serta membuat anak aktif, sehat, cerdas dan gembira. Sehingga diperlukan media alat peraga yang mampu membantu anak dalam menerima ilmu dengan cepat dan tepat.

Menurut Wijaya \& Rusyan (1994) yang dimaksud dengan alat peraga adalah media pendidikan yang digunakan sebagai perangsang belajar dengan harapan dapat menumbuhkan motivasi belajar sehingga anak didik dapat meraih tujuan-tujuan pembelajaran. Lalu menurut Sudjana (2009), pengetian alat peraga pendidikan adalah suatu alat yang dapat diserap oleh mata dan telinga dengan tujuan membantu guru agar proses belajar mengajar anak didik lebih efektif dan efisien. Alat peraga pendidikan mempunyai manfaat supaya belajar lebih cepat segera bersesuaian antara kelas dan di luar kelas alat peraga dapat memungkinkan mengajar lebih sistematis dan juga teratur.

Anak dalam melakukan aktivitas tersebut, tentunya membutuhkan berbagai alat permainan yang mengandung unsur atau nilai edukatif. Alat permainan edukatif penting untuk diberikan kepada anak-anak usia dini. Tanpa alat permainan edukatif, anak akan merasa jenuh dan bosan dalam belajar. Selain bertujuan agar anak tidak merasa bosan dan jenuh dalam belajar APE juga akan membuat anak menjadi bertambah senang dan dapat bereksplorasi dengan pembelajaran sesuai tema. Oleh karena itu, pada setiap pembelajaran di usia dini, orang tua atau pendidik perlu menyediakan alat permainan edukatif tersebut dan memilih jenis APE yang tepat untuk anak didiknya (Riany, 2009).

Alat permainan edukatif merupakan bagian yang tidak terpisahkan dalam pembelajaran anak di TK. Ketersediaan alat permainan tersebut sangat menunjang terselenggaranya pembelajaran anak secara efektif dan menyenangkan sehingga anakanak dapat mengembangkan berbagai potensi yang dimilikinya secara optimal. Pemanfaatan alat permainan edukatif dalam kegiatan belajar anak diharapkan dapat memperjelas materi yang disampaikan oleh pengajar, mernberikan motivasi dan merangsang anak untuk bereksplorasi dan bereksperimen dalam mengembangkan berbagai aspek perkembangannya.

Alat peraga metamorfosis kupu-kupu ini adalah alat yang digunakan untuk belajar memahami konsep bentuk, warna, proses terjadinya metamorfosis kupukupu. Tentunya bentuk yang digunakan lebih beragam dan mempunyai warna yang lebih mencolok. Cara anak menyelesaikan menggunakan metode mencoba dan menceritakan. Permainan ini diharapkan mampu meningkatkan keterampilan anak menyelesaikan masalah sederhana, memberikan motivasi dan merangsang anak untuk melakukan eksplorasi dan bereksperimen dalam proses tumbuh kembangnya.

Pengenalan tentang sains kehidupan mahluk hidup untuk anak usia dini dalam penulisan ini peneliti memfokuskan pada pengetahuan kehidupan Kupu-kupu. Kupu-kupu merupakan salah satu keanekaragaman hayati Indonesia yang memiliki jumlah jenis yang cukup banyak. Pengenalan makhluk hidup yang akan dikembangkan pada penulisan ini yaitu membahas tentang kehidupan kupu-kupu, dimana kupu-kupu adalah jenis bintang yang mudah di temukan disekitar lingkungan anak, mulai dengan mengenal karakteristik aneka ragam kupu-kupu yang memiliki ciri khas warna dan bentuk sayap yang indah.

Media ini diharapkan dapat menstimulasi anak-anak sejak dini dalam pengenalan kehidupan kupu-kupu dengan proses menyenangkan sehingga anak 
memahami lebih mendalam tentang karakteristik kupu-kupu, daur hidup kupukupu dan tempatt inggal atau habitat kupukupu, Dengan pengenalan kupu-kupu kepada anak sedini mungkin diharapakan dimasa depan anak lebih peka akan kelangsungan keberagaman hayati Indonesia dengan menjaga kelestarian kupu-kupu habitatnya dari kepunahan (Halimatus, et al. 2020).

\section{METODE PENELITIAN Desain Alat Peraga}

Alat peraga metamorfosis kupu-kupu ini merupakan media berbentuk kupu-kupu dan buku lipat yang disusun untuk memudahkan anak dalam menerima kegiatan pembelajaran bahasa dan sains. Desain alat peraga metamorfosis kupukupu dapat dilihat pada Gambar 1 dibawah ini.

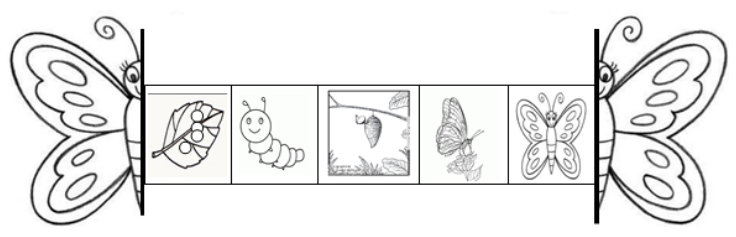

Gambar 1. Desain Alat Peraga Metamorfosis Kupu-kupu

\section{Alat dan Bahan}

Alat yang digunakan dalam pembuatan alat peraga metamorfosis kupukupu diantaranya adalah gunting, penggaris, pensil dan spidol. Sedangkan bahan yang digunakan yakni kertas asturo, kertas gambar, kertas lipat dan lem.

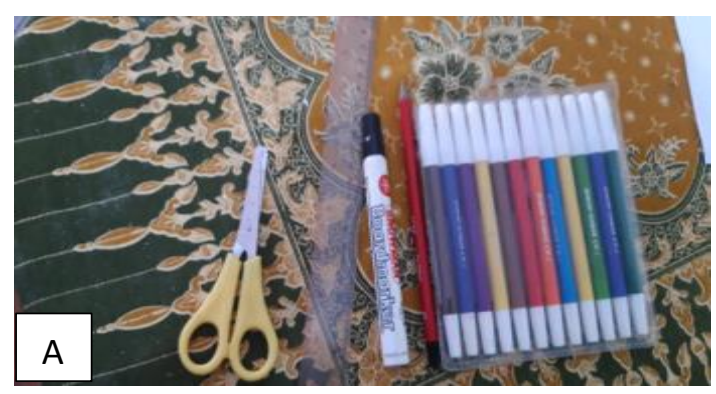

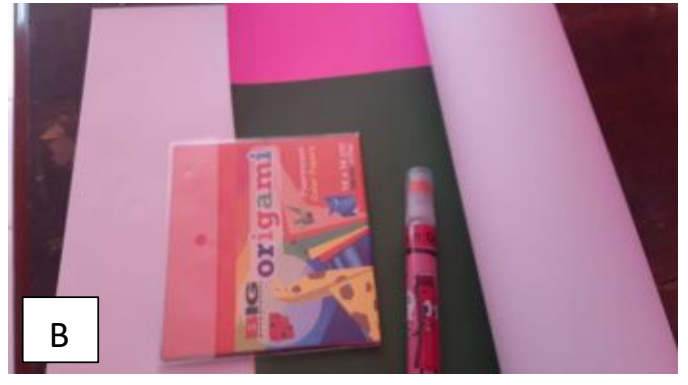

Gambar 2 (A-B). Alat dan Bahan yang Digunakan

\section{Diagram Alur Pembuatan Alat Peraga Metamorfosis Kupu-kupu}

Alur pembuatan alat peraga metamorphosis kupu-kupu dapat dilihat pada Gambar 3 di bawah ini.

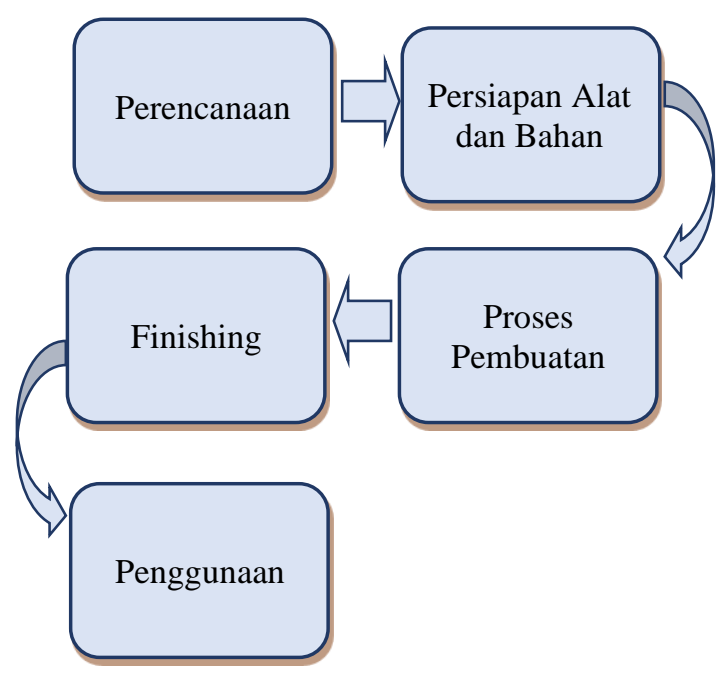

Gambar 3. Skema Alur Pembuatan

\section{HASIL DAN PEMBAHASAN Prosedur Pembuatan Metamorfosis Kupu-kupu}

Prosedur dalam pembuatan alat peraga metamorfosis kupu-kupu sebagai berikut:

1. Seluruh bahan dan peralatan yang akan digunakan dalam pembuatan dipersiapkan terlebih dahulu.

2. Kemudian dilanjutkan dengan menggambar desain kupu-kupu diatas kertas asturo dengan ukuran $25 \mathrm{~cm} \mathrm{x}$ $40 \mathrm{~cm}$, lalu digunting mengikuti pola yang telah dibuat. 


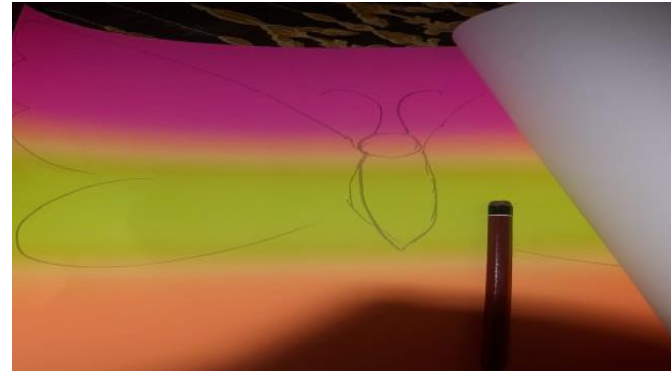

Gambar 4. Proses Menggambar Kupukupu

3. Setelah itu, potong gambar kupu-kupu menjadi 2 bagian yang sama besar.

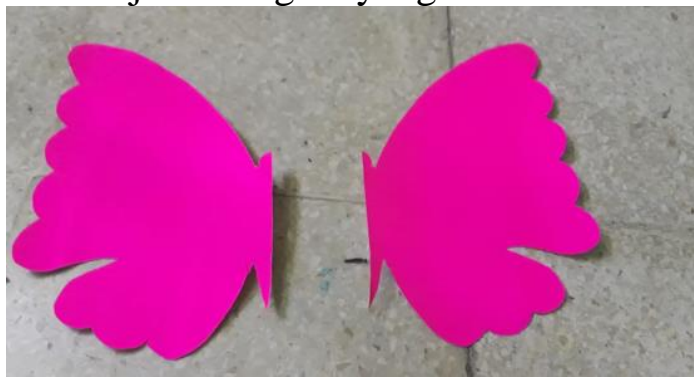

Gambar 5. Desain Kupu-kupu yang Telah Dipotong menjadi 2 Bagian

4. Kemudian kupu-kupu dihiasi dengan ornament hiasan menggunakan kertas lipat agar lebih menarik dan indah

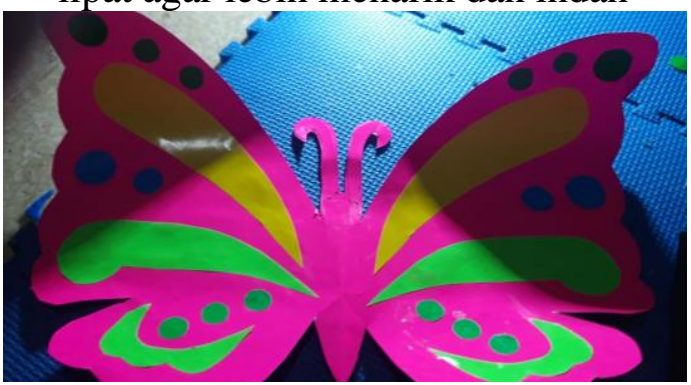

Gambar 6. Proses Menghias Kupu-kupu

5. Kemudian potong kertas gambar dengan ukuran $6 \mathrm{~cm}$ x $6 \mathrm{~cm}$ sebanyak 5 buah lalu gambari dengan spidol antara lain: telur ulat, ulat, kepompong, kupu-kupu muda, dan kupu-kupu dewasa.

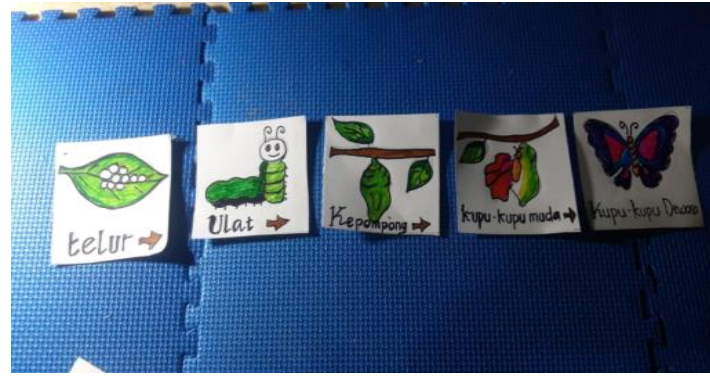

Gambar 7. Proses Menggambar Alur Metamorfosis Kupu-kupu

6. Potong kertas asturo warna hijau dengan ukuran $7 \mathrm{~cm}$ x $40 \mathrm{~cm}$, lalu kelima gambar ditempelkan pada kertas asturo dengan menggunakan lem.

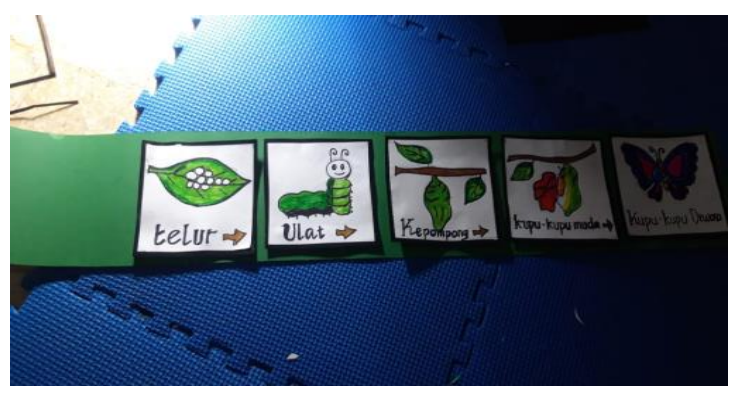

Gambar 8. Proses Penempelan Gambar Ke Kertas Asturo

7. Kemudian gambar yang telah ditempelkan pada kertas asturo kita lipat bolak-balik dengan menyisakan 1 $\mathrm{cm}$ depan dan $1 \mathrm{~cm}$ belakang lalu tempelkan pada masing-masing belahan badan kupu-kupu.

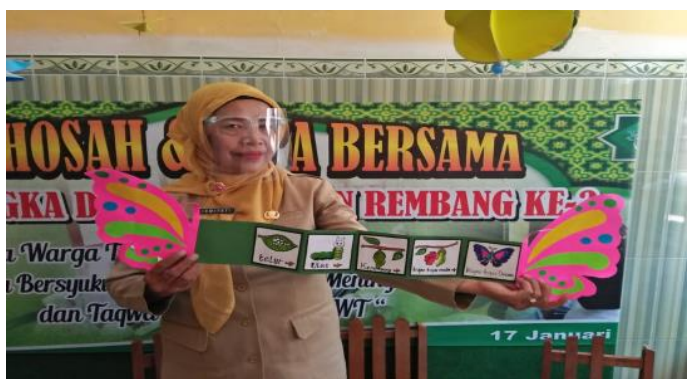

Gambar 9. Alat Peraga Metamorfosis Kupu-Kupu

Alat Peraga Metamorfosis Kupukupu digunakan untuk mengembangkan bahasa anak, meningkatkan keterampilan 
anak dan mengajak anak belajar bersosialisasi. Sebagai pendahuluan guru bercerita untuk menarik minat anak. Berikut adalah cara mengaplikasikan alat peraga metamorfosis kupu-kupu pada anak didik:

1. Untuk memotivasi anak dengan menyanyikan lagu

Kupu-kupu yang lucu

Kemana engkau terbang

Hilir mudik mencari

Bunga-bunga yang kembang

Berayun-ayun

Pada tangkai yang lemah

Tidakkah sayapmu

Merasa lelah

2. Guru memperlihatkan alat peraga pada anak

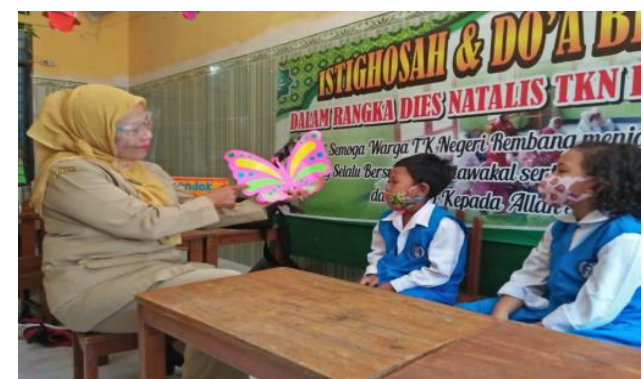

Gambar 10. Guru Memperlihatkan Alat Peraga Metamorfosis Kupu-kupu

3. Guru apersepsi bercerita mengenalkan alat peraga metamorfosis kupu-kupu.

4. Guru bercerita tentang proses siklus hidup kupu-kupu melalui urutan gambar.

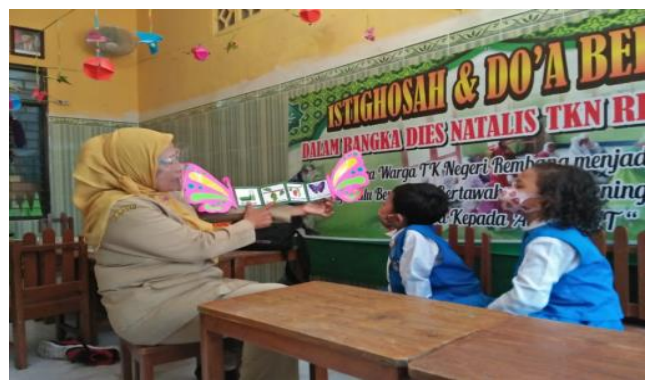

Gambar 11. Guru Bercerita Proses

Metamorfosis Kupu-kupu

5. Guru memberi kesempatan pada anak untuk mengikuti jalannya cerita dengan mendengarkan dialog atau komentar

6. Guru menjawab pertanyaan dan menanggapi komentar anak agar lebih menghayati cerita .

7. Guru memberikan kesempatan pada anak untuk menceritakan kembali (mengkomunikasikan) proses terjadinya kupu-kupu menggunakan dengan bahasa anak sendiri.

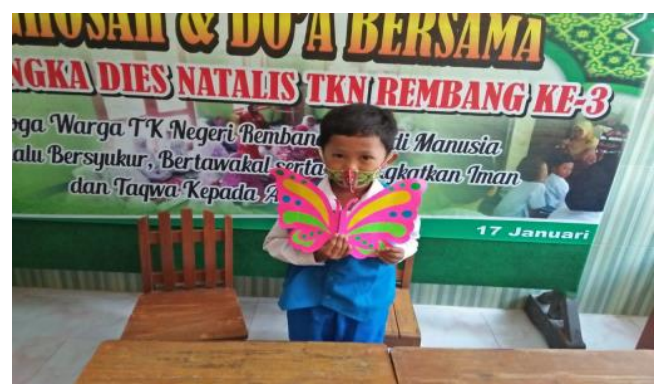

Gambar 12. Anak Mencoba Alat Peraga

8. Guru memupuk dan mendorong keberanian anak menceritakan kembali cerita dengan alat peraga metamorfosis kupu-kupu.

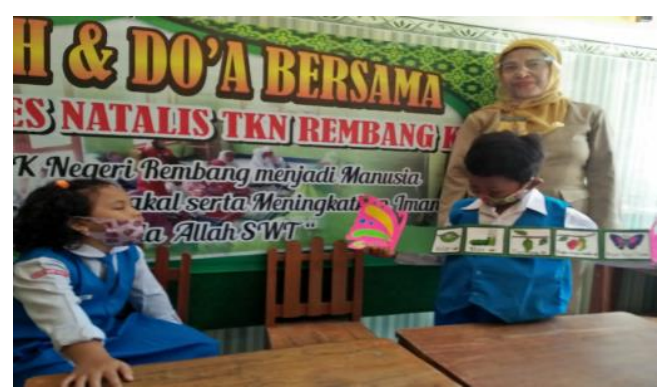

Gambar 13. Anak Berani Mencoba Menceritakan Kembali

9. Guru melakukan pengamatan terhadap penampilan anak dalam memainkan alat peraga metamorfosis kupu-kupu.

Hal diatas menjelaskan bahwa pendidikan anak usia dini diberikan pada anak agar dapat berkembang secara optimal. Mengingat pentingnya masa ini, maka peran stimulasi berupa penyediaan lingkungan yang kondusif harus disiapkan oleh para pendidik, baik orang tua, guru, pengasuh, ataupun orang dewasa lain yang 
ada disekitar anak, sehingga anak memiliki kesempatan untuk mengembangkan seluruh potensinya. Abidin (2009) mengatakan bahwa potensi yang dimaksud dalam pendidikan anak usia dini meliputi aspek moral dan nilai-nilai agama, sosial, emosional, dan kemandirian, kemampuan berbahasa, kognitif, fisik/motorik dan seni.

Anak juga diajak untuk mengamati bagaimana transformasi kupu-kupu dari telur menjadi ulat kemudian berubah menjadi kepompong dan akhirnya berproses menjadi kupu-kupu dewasa, penomena siklus kehidupan Kupu-kupu melaui tahapan-tahapan metamorfosis ini sangat menarik untuk diamati anak-anak. Anak juga biasa mengenal lingkungan dan tempat tinggal Kupu-kupu, dimana kupukupu banyak ditemui di dalam hutan. Serangga ini biasa beterbangan di antara pohon-pohon di dalam hutan, di tepi-tepi sungai dan tempat-tempat lain yang terang dan terbuka di dalam hutan yang terdapat berbagai jenis bunga dimana Kupu-kupu amat tertarik dengan bunga berwarna cerah dan penuh warna.

Pada anak usia dini untuk merangsang dan mengembangkan kreativitas adalah dengan kegiatan bermain yang dilakukan dilingkungannya dengan menggunakan sarana, alat permainan yang edukatif dan memanfatkan sumber belajar untuk merealisasikan kegiatan-kegiatan yang kreatif. Kegiatan bermain itu sendiri sebenarnya ada yang dapat dilakukan tanpa menggunakanalat tetapi pada umumnya kegiatan bermain lebih banyak menggunakan alat. Sehingga tercipta egiatan yang sangat menyenangkan, cara atau alat pendidikan yang bersifat mendidik dan bermanfaat untuk meningkatkan kemampuan berbahasa, berfikir, serta bergaul dengan lingkungan, juga bermanfaat untuk menguatkan dan menerampilkan anggota badan si anak, mengembangkan kepribadian anak (Ismail, 2011)
Selama ini pada kegiatan bercerita kurang menarik bagi anak, beberapa anak juga asyik ngobrol sama temannya, bermain sendiri, dan juga tidak memperhatikan cerita guru, terlebih saat disuruh menceritakan kembali anak masih belum ada yang berani. Dengan adanya alat peraga metamorfosis kupu-kupu, anak-anak menjadi sangat antusias dan ingin tahu ketika guru mulai bercerita sampai dengan akhir cerita. Mereka sangat tertarik dengan media metamorfosis kupukupu yang dipakai sebagai alat bercerita dan juga antusias dalam mendengarkan cerita. Kemudian guru memberi kesempatan kepada anak secara bergantian untuk bercerita bagaimana proses terjadinya kupu-kupu.

Melalui kegiatan bermain, daya pikir anak terangsang untuk mendayagunakan aspek emosional, sosial serta fisiknya. Lewat permainan, anak-anak dapat mempelajari banyak hal. Oleh karena itu, dengan bermain, anak-anak akan bertambah kemampuan fisik, pengalaman dan pengetahuannya, serta berkembang keseimbangan mentalnya. Permainan edukatif dirancang untuk menggali kemampuan anak, termasuk kemampuannya dalam berkonsentrasi, anak dituntut untuk fokus pada gambar atau bentuk yang ada di depannya, ia tidak berlari-larian atau melakukan aktivitas fisik lain sehingga konsentrasinya bisa lebih tergali.

Permainan edukatif sangat baik biladibarengi dengan penuturan cerita. Hal ini akan memberikan manfaat tambahan buat anak yakni meningkatkan kemampuan berbahasa juga keluasan wawasan. Dari mainan edukatif anak dapat mengenal ragam/variasi bentuk dan warna. Ada benda berbentuk kotak, segiempat, bulat dengan berbagai wama seperti biru, merah, hijau dan lainnya (Suryadi, 2007).

Kegiatan pembelajaran perlu memberikan dorongan kepada peserta didik dalam mengungkapkan kemampuannya dalam membangun 
gagasan. Guru berperan sebagai fasilitator dan bertanggung jawab untuk menciptakan situasi yang dapat menumbuhkan prakarsa, motivasi dan tanggung jawab peserta didik untuk belajar. Disamping itu, guru dalam mengelola pembelajaran hendaknya mampu mengembangkan pola interaksi antar berbagai pihak yang terlibat didalam pembelajaran dan harus pandai memotivasi peserta didik untuk terbuka, kreatif, responsif, interaktif dalam kegiatan pembelajaran (Syamsuardi, 2012).

Alat peraga ini sangat membantu proses pembelajaran karena penyampaian materi menjadi menarik dan menyenangkan, anak-anak pun juga mulai berani untuk bercerita, sehingga hasil yang didapat pun memuaskan. Terdapat beberapa aspek yang dikembangkan dengan implementasi alat peraga metamorfosis kupu-kupu diantaranya adalah:

1. Nilai Agama dan Moral

a. Mempercayai adanya Tuhan melalui ciptaan-Nya

2. Sosial Emosional dan Kemandirian

a. Memiliki perilaku yang mencerminkan sikap taat terhadap aturan sehari-hari

b. Memiliki perilaku yang mencerminkan sikap sabar (mau menunggu giliran mau mendengarkan ketika orang lain berbicara) untuk melatih kedisiplinan

3. Fisik Motorik

a. Menggunakan anggota tubuh untuk pengembangkan motorik kasar dan halus

4. Kognitif

a. Memiliki perilaku yang mencerminkan sikap ingin tahu

b. Memiliki perilaku yang mencerminan sikap kreatif.

c. Mengtahui cara memecahkan masalah sehari-hari dan berperilaku kreatif.

d. Menyelesaikan masalah seharihari secara kreatif. e. Mengenal benda-benda di sekitarnya (nama warna bentuk ukuran pola sifat suara tekstur fungsi dan ciri-ciri lainnya).

f. Mengenal lingkungan alam (hewan, tanaman, cuaca, tanah, air, batu-batuan dan lainnya).

5. Bahasa

a. Memahami bahasa reseptif (menyimak dan membaca).

b. Menunjukkan kemampuan berbahasa reseptif (menyimak dan membaca).

c. Memahami bahasa ekspresif (mengungkapkan bahasa secara verbal dan non verbal).

d. Menunjukkan kemampuan berbahasa ekspresif.

e. Mengungkap bahasa verbal dan non verbal.

6. Seni

a. Mengenal lingkungan alam (hewan, tanaman, cuaca, tanah air, batu-batuan dan lainnya).

b. Menyajikan berbagai karyanya dalam bentuk gambar bercerita. Bernyanyi gerak tubuh dan lainnya tentang lingkungan alam (hewan, tanaman, cuaca, tanah, air, batuan dan lainnya).

\section{KESIMPULAN}

Berdasarkan hasil dan pembahasan penggunaan alat peraga metamorfosis kupu-kupu dapat disimpulkan bahwa alat peraga metamorfosis kupu-kupu digunakan pada pengembangan dengan pembelajaran melalui pengalaman belajar sambil bermain untuk membantu mengembangkan kemampuan anak dalam berbahasa, mengenal warna, sains dan kemampuan anak dalam memahami bahasa reseptif dan ekspresif.

\section{UCAPAN TERIMA KASIH}

Terima kasih disampaikan kepada pihak-pihak yang telah membantu dalam proses penelitian ini sehingga dapat selesai 
dengan baik dan tepat waktu. Terima kasih disampaikan kepada para dosen dan rekan sejawat.

\section{DAFTAR PUSTAKA}

Abidin, Y. (2009). Bermain. Bandung: Rizki Press

Asri, N. (2020). Pengembangan Alat Permainan Edukatif Maze Tiga Dimensi Subtema Hewan Kupu-Kupu Padaanak Kelompok B Di Taman Kanak-Kanak. [Skripsi]. Palembang: Universitas Sriwijaya.

Halimatus, L. Fridani, \& S.M. Meilani. (2020). Pengembangan Media Grafis untuk Pengenalan Life Science pada Anak Usia Dini. Jurnal Obsesi : Jurnal Pendidikan Anak Usia Dini, 4(1): 395-405

Ismail, A. (2011). Alat Peraga \& APE, Yogyakarta: Shibiyan.
Riany, A. (2009). Alat Permainan Edukatif Lingkungan Sekitar untuk Anak Usia 0-1 Tahun. Bandung: Sandiarta Sukses.

Sudjana, N. (2009). Penilaian Hasil Proses Belajar Mengajar. Bandung: Remaja Rosdakarya.

Suryadi. (2007). Cara Efektif Memahami Perilaku Anak Usia Dini. Jakarta: EDSA Mahkota.

Syamsuardi. (2012). Penggunaan Alat Permainan Edukatif (APE) Ditaman Kanak-Kanak PAUD Polewali Kecamatan Tanete Riattang Barat Kabupaten Bone. Jurnal Publikasi Pendidikan, (11) 1: 59-67

Wijaya \& Rusyan. (1994). Kemampuan Dasar Guru dalam Proses Belajar Mengajar. Bandung: Remaja Rosdakarya. 